\title{
Russian Politics Toward Ukraine: was there Ever a Strategic Partnership?
}

Relations between Russia and Ukraine through the prism of strategic partnership concept were discussed in much research in Ukraine and abroad. Among others there was the book of Michael Emerson, Nathalie Tocci, Marius Vahl, and Nicholas Whyte where scientists thought about rivalries of the European Union and Russia on the space that the new Russian political vocabulary calls the "Near Abroad" (Emerson, Tocci, Vahl, Whyte, 2001). Ukrainian researchers first of all tried to compare the case of RussianUkrainian relations with other Ukrainian partners (Парахонський, 2005; Парахонський, Яворська, 2011; Пивоваров, 2009; Седляр, 2005). Yulia Sedliar revealed the peculiarities of the Russian-Ukrainian strategic partnership before the Orange Revolution. For her even then the unequal nature of our relations stood in the way of our common politics in different spheres of cooperation. However, these works do not embrace a period after 2013 and does not give an opportunity to reduce the character of Russian politics in Ukraine throughout the period of Ukrainian independence.

The nature of the development of Russian-Ukrainian relations is not clear and needs to be revealed. The hypothesis of this research was that these states never had a rich level of strategic partnership (despite the officially proclaimed status), but always remained a sort of "negative strategic dependence" because of the high level of asymmetry in their relations.

Try to lead to our idea from the opposite framework. Although relations of strategic partnership must be equal, some researchers notice that strategic partnership is possible when there is asymmetric cooperation between parties: one of the partners is dependent upon the other (Blanko, 2011; Slobodchikoff, 2013). In particular, Ukraine had such relations from the Russian Federation and the USA. For providing to the foreign-policy interests of world leaders in different regions such as the European Union, China, and the USA, it elects small or middle countries as their strategic partners that allow these leaders to gain access to the key natural resources and transport infrastructure or grow a regional military presence. And for the small/middle states such strategic collaboration can become an important safety factor, restrain aggression of other actors, etc. (Тоді, 2001).

However, strategic partnership cannot exist when participants are succeeded to discriminatory actions to each other through the presence of political, economic, cultural, 
and soldiery advantages; in fact, strategic partners must settle problem situations at the level of political dialogue (Перепелиця, Заремба, Д’аньєрі, Кременюк, 2005). This seems to be the case of Russian-Ukrainian relations which demonstrates exactly the limit in possibilities for strategic partnership by different-large states.

According to expert opinions, efficiency of strategic partnership shows up fully through symmetry of collaboration that allows both parties to show general position on international forums and expose own productive-export potential otherwise it is difficult to ground the necessity of tactical losses for the achievement of important strategic aims (Moraes, 2015; Subramanian, 2016). Efficiency of strategic partnership increases when such cooperation is confessed by influential international actors (Le The Mau, 2016). Summarizing the raised positions, scientists mark that strategic partnership opens up through the presence of such intergovernmental collaboration that allows parties to combine effort, arrive at important foreign-policy aims, and also demonstrate integral of long duration inter-branch cooperation. Although, if Lucyna Czechowska wrote about the concept of strategic partnership as a part of alliance relations (Czechowska, 2013), Hryhorij Perepelytsia tried to divide "strategic partnership" and "relations of allies" (Перепелиця, Заремба, Д’аньєрі, Кременюк, 2005).

Ihor Zhovkva proved that the attribute of strategic partnership is community of strategic interests. Without its further reflections existing relations are superfluous (Жовква, 2005). Grygorij Perepelytsia marked that scientists must distinguish two definitions of strategic partnership - as a level of the attained cooperation and as an instrument of state foreign policy (Перепелиця, Заремба, Д'аньєрі, Кременюк, 2005). Building off from these two works, in the given article strategic partnership is examined in the next two measures. The first part is sanctified to the use of the concept of strategic partnership in the foreign policy of the Russian Federation (on the example of Ukraine), and second to accordance of level of their cooperation proclaimed strategic partnership.

\section{THE CONCEPT OF STRATEGIC PARTNERSHIP IN THE FOREIGN POLICY OF RUSSIAN FEDERATION: THE EXAMPLE OF UKRAINE}

Treaty on Friendship, Cooperation, and Partnership between Ukraine and the Russian Federation, which was signed in Kyiv on May 31, 1997, established the principles of "strategic partnership, recognition of the inviolability of existing borders, respect for territorial integrity, mutual commitment not to use their respective territories to harm the security of one another" (Договор о дружбе, 1999).

Some time passed and among more than twenty strategic partners of Russia was already not Ukraine, but from 2015 there is the unrecognized Republic of Abkhazia. Meantime, in the presidential decree on Strategy of National Safety of the Russian Federation again declared, "maintenance of the proper international and regional strength security only on the basis of justice principles of international law" (O Стратегиu, 2015), and the speech on Conception of Foreign Policy of the Russian Federation goes on about development of equality in strategic partnership (Концепция внешней политики, 2016). Thus, it follows to pay attention to the question about sources of 
distance from the declared equality of rights as a key principle of strategic partnership to completion of this partnership with a country that was one of the most important in Russian strategy of national safety.

The significance of Ukraine for Russia was determined by several key factors. The most important among them is the position of Ukraine as a transit corridor for Russian oil and gas on the way to customers in the EU. The next factor was different economic assets of Ukraine from metals to telecommunications, which were interests for Russian business-groups. In addition, Ukraine is home to the largest portion of the Russianspeaking population outside the RF which lives in the East and South of Ukraine. Finally, the Russian Orthodox Church considers Ukraine along with Russia and Belarus as an integral part of its 'canonical territory.'

Between 2003 and 2005 radical changes in Russian foreign policy took place when the Kremlin defined the RF as the great state, insisting that both the United States and the European Union should treat Russia as an equal partner (Piontkovsky, 2017). Vladimir Putin's accession to power coincided with a period of high energy prices which rose tenfold during the first eight years of his presidency. During this period, the economic field of the RF followed the classic course of an authoritarian oil-producing country: profits from the sale of energy resources either corroded or accumulated in gold reserves. Based on the model of the energy resources of the Putin regime, it was possible to increase Russia's GDP 4 times from about 350 billion dollars in 2000 to 1,400 billion dollars in 2008 and to accumulate more than 500 billion dollars in reserves (Горбулін, Литвиненко, 2010). At this time, all ideologies were consolidated in the country on a great power base, and the dissolution of the Soviet Union was officially recognized as the largest geopolitical catastrophe of the $20^{\text {th }}$ century. So, if in the 1990s Moscow agreed with the geopolitical vacillation of Kyiv between Russia and the West, in 2003 it made an attempt to draw Ukraine closer. The Eurasian Union (Russia, Belarus, Kazakhstan, and Ukraine) led to the economic alliance and to the creation of political and security group under the auspices of Moscow.

The new feature of the first decade of $21^{\text {st }}$ century was that the Kremlin significantly increased its own media arsenal. The traditional media market in the Russian Federation was quite divided between state-owned Gazprom-media and the National Media Group (11 of the 17 largest television networks) which are controlled by Putin's personal friends. An important role was played by central television; it remains the leader of the audience with a volume of $74.3 \%$ daily and $91.1 \%$ weekly (Pasitselska, 2017: 595). Russia established the Federal Agency for CIS Affairs, compatriots living abroad, Rossotrudnichestvo (for international humanitarian cooperation), created by Medvedev in September 2008 (analogue of USAID). Although it is subordinate to the Ministry of Foreign Affairs of the Russian Federation, the leadership is exercised by the head of state. Today, the activities of Rossotrudnichestvo and its overseas agencies are aimed at the approval abroad for the 'correct' understanding of modern Russia, its potential, and the content of the country's course (Олішевська, 2015). As for the financing of Rossotrudnichestvo, at the beginning of June 2013, President Putin approved the allocation of almost 330 million dollars for improving the image of Russia abroad. There are other elements of soft power of the Russian Federation which do not function independently, but are still considered as NGOs: the Russian Association for International Cooperation 
(more than 70 public associations, for example, Russkiy Mir Foundation, the Foundation of St. Andrew the First-Called, the Russian Abroad Library Fund), the Russian Fund for Culture, the International Council of Russian Compatriots, the International Union of Museums, etc. Among the information partners of Rossotrudnichestvo, it is worth mentioning "ITAR-TASS," RIA "Novosti," "Russia Today," "TVC" TV channels, "MIR" TV company, "Voice of Russia" radio station, and others.

Ukraine's political relations with Russia were always complicated because of the specific character of understanding of the Kremlin what does it mean to be partners. Periods of tension shifted with periods of relative calm. Instead of trying to integrate with the West, Russia set out to create a system with a centre in the Kremlin on the territory of almost all of the former USSR. In this worldview, Ukraine took a significant place. Russia did not seek 'a reunion' with Ukraine. The goal of Moscow was 'a friendly and neutral Ukraine' so to speak, a later version of Finland, located between Russia and the West, but by no means not 'Ukraine as a part of the West' (if Ukraine were to choose European and Euro-Atlantic integration). According Russian scientist Dmitri Trenin, "The leaders and elites of Russia see Ukraine as a sum of profitable assets and attractive opportunities, but not like a territory which must be attached to Russia" (Trenin, 2007: 197). However, a significant number of Russians saw Ukraine as a separate state, but not like alien foreign country.

The Kremlin made a huge miscalculation when developing its strategy before the 2004 presidential election in Ukraine. It relied on the single candidate of the "party of power,' who was promoted by the former President Kuchma. Then Prime Minister Yanukovych was considered a pro-Russian politician. Gleb Pavlovski, the Kremlin political strategist who worked for Yanukovych on behalf of Kremlin, noted that the conditions of his contract with the Administration of the Russian President included securing victory in the elections he had prepared (although it was challenged by the Ukrainian opposition), and did not include the obstruction of the Revolution (Trenin, 2007: 197).

After the Orange Revolution in 2004 there was a sense of threat. Democratic development of Ukraine (whether it wants it or not) influences the internal social and political development in Russia. Secondly, the Russian Federation feared that the ultimate goal of the United States and the EU was to facilitate a change of the regime by organizing a colour revolution in Russia itself (Barbashin, Thoburn, 2017). Thus, Ukraine, like Central Asia and the South Caucasus, was viewed by the Kremlin as a 'battlefield' with the West. For the Kremlin, this greatly increased the 'price' of defeat in these areas. Putin staked both traditional Russian patriotism and a new post-imperial nationalism. The official nationalism of the Kremlin has been reflected in such twin-concepts as "sovereign democracy" and "energetic superpower," which came to the force in 2005 (Piontkovsky, 2017).

According to social polls after 2004, Russians stably showed a more negative attitude to Ukrainians then and vice-versa. Ukraine's attempts to reorient towards the EU and NATO were assessed as anti-Russian and hostile. Among the most discussed issues in Russia that hurt Ukraine in the eyes of Russians were: attempts by Ukraine to recognize the Holodomor as a genocide against the Ukrainian nation; attempts to rehabilitate the Ukrainian Insurgent Army (UPA); discussion in Ukraine over whether it was necessary to provide official status to the Russian language, or to make it the second official language (White, McAllister, Feklyunina, 2010: 348). 
Soon after the Orange Revolution, Moscow understood that it was necessary to change tactics but not its strategy towards Ukraine. The new one was based on four key elements: 1) ignoring the pro-Western policy of Kyiv, especially the ambitions regarding NATO at the official level; 2) provocation for destabilization within Ukraine by deepening the historical division of the country and restraining the movement towards NATO; 3) using direct economic, social, and cultural pressure as an instrument of foreign policy; 4) offering assistance in security through various forms of cooperation with the CIS or bilateral channels.

At this time the Kremlin's ideologues insisted that Ukrainians wanted reunification with Russia, but Ukrainian authorities are hindering public desires. The policy of the RF in the post-Soviet space was based on the concept of responsibility for its citizens abroad, for ethnic Russians and even simply Russian-speakers, who are officially called 'compatriots.' Representatives of the Russian political elite continued to argue that the Ukrainian language is just a Russian dialect and that Ukraine (as well as Belarus) should become part of the Russian Federation. In June 2010, Mikhail Zurabov, the former Russian Ambassador to Ukraine, said that, "Russians and Ukrainians are one nation with their own nuances and peculiarities" (Brusylovska, 2015). In addition, Ukrainian history was not considered a separate subject in Russian universities; it was always included into Russian history.

In August 2008, Oleksandr Sushko wrote about a possible scenario of Russian strategy: "If the West forgives Russia for the Georgian war, a 'peacekeeping' invasion on the territory of Ukraine will only be a matter of time. Since the beginning of the massive invasion of the regular army on the Georgian territory, Russia has begun a geopolitical war aimed at destroying the existing world order. Ultimately, a revanchist strategy may lead to the destruction of Russian statehood; however, before it happens, multiple local conflicts will erupt, eliminating the rudiments neighbouring countries' independence... The Russians deliberately prepare themselves for a war with Ukraine. In Russia, the absence of war causes excitement, instability, and a decline in national pride. Periods of national enthusiasm were almost entirely related to wars. Putin started with Chechnya and Medvedev with Georgia. The motto "Our citizens are there" helps to create a sense of quasi-legitimacy which is enough for Russian citizens. ... They were told that it was not a war against brotherly people, but a war against 'the criminal government"” (Сушко, 2008). This scenario came into force in 2014 when all four Russian-Ukrainian agreements on the Black Sea Fleet were denounced by the Russian State Duma unilaterally (March 31, 2014). Kyiv has condemned Russia's termination of these agreements as unlawful, considering that Russia itself violated their terms, and on September 21, 2018, the Ukrainian MFA transmitted to the Russian side a note on the decision not to extend the Treaty on Friendship. The law of Ukraine No. 2643-VIII (December 6, 2018) terminated the Treaty from April 1, 2019. The law referred to the Vienna Convention (Art. 60) governing the termination of a treaty by reason of its breach (Любашенко, 2019: 166).

So, the RF itself refuses from using 'strategic partnership' as instrument of its policy towards Ukraine. New strategy bases on several narratives that could be easily investigated through Russian media. Firstly, 33\% of all references to Ukraine are connected with the thesis that a civil war continues in Ukraine: There is a focus on com- 
munication and delegitimization of the Armed Forces of Ukraine. Secondly, Russia presents Ukraine as an 'underdone-state' or failed state. Thirdly, the Russian government describes Ukraine as a Russophobic state where the Russian-speaking population is persecuted. Fourthly, $6 \%$ of Russian media uses the thesis that Ukraine is a puppet of the West: "If Ukraine, for example, has reached Visa-free, this happened because the West is engaged in flirting with Ukraine. If Ukraine is not given something, it means that the West punishes its puppet Ukraine," explained Ruslan Kavatsyuk, analyst of the Hybrid Threat Analysis Group, advisor to the Vice Prime Minister for European and Euro-Atlantic Integration of Ukraine (УКМЦ, 2018).

Before Viktor Yanukovych left Kyiv, Moscow said that it would not interfere in the internal conflict of Ukraine and accused the Western countries which showed solidarity with Euromaidan. Moscow believed that Yanukovych would be able to restore control over the country. After 2014, Russia preferred hard power instruments that were totally incompatible with the essence of the 'strategic partnership' concept.

Why did Moscow choose hard power? In our opinion, if at this moment it failed to change the vector of development for Ukraine, then not only would any further activity become meaningless, but also the RF would gradually lose hope for the restoration of superpower status. Putin himself explained the origin of the Russian-Ukrainian conflict being the haste with which the European Union sought association with Ukraine: "It was unacceptable for Russia, because it encroached on our interests in the neighbouring country" (Darczewska, 2014: 4) Nikolai Patrushev the secretary of the Security Council of the Russian Federation interpreted the events in Ukraine as, "the following steps of the plan to destroy the Soviet Union and then Russia" (Darczewska, 2014: 4). In this context, the annexation of Crimea and the conflict over "Novorossiya" were just separate incidents of the "Cold War" between Russia and the West. Conditionally, its beginning can be attributed even before both Putin's first presidency and George W. Bush's presidency. During one of Bush's speeches in 2004 he said, "I believe that God has planted in every human heart the desire to live in freedom. And even when that desire is crushed by tyranny for decades, it will rise again" (Darczewska, 2014: 10). The intention of the USA to promote the expansion of democracy over the world was perceived by Russia as an invasion of the West on the territory which was considered as a space of its vital interests (neighbouring countries). The Russian doctrinaires said that in fighting with liberal globalization, first of all, Russia resisted anarchy ("global Maidan," denial of all hierarchic rules) and protected the sovereignty and the right of nations to choose their own values. The new 'Cold War' became a war of interpretations. The proper interpretation is multiplied by all possible means, while the 'alien' interpretation is marginalized. The aim is to neutralize the enemy, to support allies, and to win unsolved disputes (Darczewska, 2014: 6). So, in some sense, Russia lost because all its efforts to maintain the role of Ukraine being an obedient junior partner failed.

\section{LEVEL OF COOPERATION OF RUSSIA WITH UKRAINE}

During the 1990's, both countries, along with other post-Soviet states, founded the Commonwealth of Independent States and re-established business relations. Despite the contradictions over the island of Tuzla, relations with Ukraine and RF gradually 
improved during the governance of Leonid Kuchma (1994-2004). These relations were built primarily on an economic basis. While the Russian share in Ukraine's exports decreased from $26.2 \%$ in 1997 to about $23 \%$ in 1998-2000, the share of Russian imports remained stable at 45-50\% (Astrov, Havlik, 2007: 140). The level of imports from Russia remained high due to dependence on Russia's energy resources.

Meanwhile, progress in economic integration with Russia was problematic to a large extent due to political reasons. Russia widely used a ban on the import of some goods to Russia as a political instrument. For example, after 2004 there was a ban on the import of dairy and meat products from Ukraine (Astrov, Havlik, 2007: 140). In 2004, $84 \%$ of Ukrainian exports belonged to other markets except Russia. The main reason for the relative decline in Russian was the need for RF goods to meet Western standards, as well as in the gradually weakening ties among enterprises in the post-Soviet space. However, Ukraine's dependence remained extremely strong in the energy sector: annually about $70-75 \%$ of gas usage and about $80 \%$ of petroleum were imported from Russia. In 2002, the Russian government participated in financing the construction of nuclear power plants in Khmelnytsky and Rivne, Ukraine. Russia remained the main market for Ukrainian metals, rolled steel and pipes, electrical machinery, tools and equipment, food, and chemical products, which were the sales market for about nine-tenths of Ukrainian goods. Despite the slowdown of development, Russia was in fourth place among investors in the Ukrainian economy (after the USA, the Netherlands, and Germany): 150.6 million dollars of 2,047 million dollars of direct investments, which Ukraine received before 1998 (Astrov, Havlik, 2007: 141).

Considering the surplus of energy as its main advantage, the Russian government sought to secure its dominance in the energy sector of the country. Energy supply was a big problem, as Soviet oil and gas pipelines to Western Europe passed through Ukraine. After the new agreements came into force, Ukraine's gas debts were paid for Russia's transfer of nuclear weapons, which Ukraine inherited from the USSR (including the TU-160 strategic bombers) (Дубовик, 2016: 255).

After the Orange Revolution in 2004, bilateral relations between Russian and Ukraine worsened immediately. A lot of analysts emphasized the subjective factor and considered that to be responsible for the deterioration of relations between Ukrainian President Viktor Yushchenko, Russian President Vladimir Putin, Mayor of Moscow Yuri Luzhkov, Minister of Foreign Affairs of Ukraine Borys Tarasyuk, and the leader of the parliamentary opposition Yulia Tymoshenko (Emerson, 2007).

A large group of differences in Russian-Ukrainian relations were related to the Russian military base in Crimea, and, in particular, the basing of Russian Black Sea Fleet in Sevastopol. Firstly, it was a question the ownership of Crimea, which has been under control of the Ukrainian Soviet Socialist Republic since 1954. As a result of treaties from the 1990s, Crimea remained a part of Ukraine, but it gained a republican autonomous status. Secondly, there was controversy over Sevastopol's status as a base of the Black Sea fleet. The city, along with other parts of Ukraine, took part in the national referendum on Ukrainian independence in 1991, and $58 \%$ of its population voted to remain as an integral part of Ukrainian state (Брусиловська, 2016). However, the State Duma of Russia demanded a return of Sevastopol in 1993. After several years of intense negotiations, in 1997 the problem was resolved with 
a compromise: The Black Sea fleet was divided and some Black Sea bases in Sevastopol were rented to the Russian fleet until 2017 (Соглашение о параметрах, 1999; Соглашение о статусе, 1999).

Since signing the Russian-Ukrainian Treaty in 1997, Ukraine considered a large number of disputes to be caused by the deployment of the Black Sea Fleet in Ukraine, which did not receive a final decision. At the technical level, the main issues of concern were the status and functioning of Russian military tribunals in Crimea, the transfer of hydrographic and navigational equipment to Ukraine, the inspection of the Black Sea Fleet by Ukraine, the number of military contingents placed in Ukraine, the inventory of occupied space and equipment leased to the Black Sea Fleet, as well as an agreement on joint actions in emergencies. Some of the above issues, such as moving hydrographical and navigational equipment to Ukraine, were fundamentally excluded by the Russian side from the Russian-Ukrainian sub commission's program for the Russian Black Sea Fleet until the end of the lease term in 2017 (Брусиловська, 2016). Other questions, such as the regime of border crossing for Russian troops and modernization of the fleet were the matters for negotiations on the highest level. For Russia, the question of extending the right to set up the Black Sea Fleet in Crimea after 2017, when the current contract expired, became a key issue. It was also important for the Russian Federation to maintain the use of two early warning radars in Mukachevo and Sevastopol, which the Russian Federation rented in Ukraine. Another constant controversy was the border in the Azov Sea near Kerch Strait. Serious problems in relations were revealed by mass protests organized against 'Sea Breeze' exercises in Crimea in 2006: Russian Intelligence Services and Black Sea Fleet personnel took part in preparing anti-NATO attacks along with Yanukovych's Party of Regions (Kovalova, 2007: 180).

'The point of no return' for bilateral relations was 2008. It began with the fact that in February, Russia unilaterally withdrew from the Ukrainian-Russian intergovernmental agreement on SPRN, signed in 1997. On the eve of the conflict between Georgia and the Russian Federation, Russia artificially increased the number of 'Russians' in Georgia by distributing passports to those who wanted it; the same happened in Crimea where their number increased from 2,000 to 100,000, and in Ukraine it increased to 543,000 (Popescu, Wilson, 2009: 42). Vice-versa, during the Russo-Georgian War, Ukraine instructed the Russian Black Sea Fleet in Sevastopol to obtain permission before crossing the Ukrainian border. Russia refused to do it (Схануров, 2018).

Russia's pressure on Ukraine through the informational sphere was most active during the period of 2005-2009. One of the main topics on the pages of print media and on TV was the issue of relations between the two countries in the gas field. Since 2005, these relations acquired signs of a 'gas war': "each time, before signing a new contract for the supply of Russian gas to Ukraine, the Russian media launched a campaign to discredit Ukraine in the eyes of the world community accusing the country of theft of Russian energy resources" (Ялі, Філенко, 2013). In January 2009, the dispute over natural gas prices resulted in a 'gas war': Russian natural gas exports through Ukraine were closed. Relations worsened further in February of 2009 after Russian President Dmitry Medvedev's statement that Ukraine should compensate for the gas losses of European countries. Following the publication on March 23, 2009, of a plan for the modernization of the natural gas infrastructure of Ukraine, with the participation of the EU, Russian 
energy minister S. Shmatko said that this harms the interests of the Russian Federation. According to Putin, "it is just not serious to discuss such problems without the main supplier" (Piontkovsky, 2017). An interesting tendency was observed throughout the gas conflicts in 2005-2009: by the time the two countries reached an agreement on the gas issue, the information was presented exclusively negatively (ironic and evaluative judgments, political scientists' comments on the wrong actions of the government, interviews of individual Ukrainian politicians with threats of impeachment of the government and the president). After the signing of a gas agreement, the presentation of news from Ukraine immediately became balanced. This clearly indicated the manageability of campaigns in the Russian media from a single centre (Ялі, Філенко, 2013).

On August 11, 2009, President Medvedev criticized Yushchenko for the deterioration of relations between Russia and Ukraine and his 'anti-Russian position of the authority.' Medvedev emphasized that he would not send a new ambassador to Ukraine to improve relations (Mendelson, 2017). All their hopes were connected with new political elections, which Yanukovych could win not by Russian support but by the internal differences among Ukrainian 'Westerners.'

Viktor Yanukovych (2010-2014) was the most pro-Russian and pro-Soviet President of Ukraine. Since coming to power, he met all the requirements put forward by the Russian Federation. On April 22, 2010, Yanukovych and Medvedev signed an agreement on the lease of Russian naval base in Sevastopol for the next 25 years. The Kharkiv Accords were ratified on April 27 (Угода, 2010). In return, Ukraine received discounts for natural gas supplies of 100 dollars per thousand cubic meters. In 2010 , about $70 \%$ of the economic potential of Ukraine was under the control of Russian capital. During last 10 years in the Verkhovna Rada and government, 'regionalists' and 'communists' have created a strong pro-Russian lobby. The Russian Intelligence Services established control over the security forces of Ukraine - army, police, and security service.

Before 2014 Russia paid attention first to soft power instruments and among them was culture. Cinema is a significant part of mass culture aimed at the formation of society's consciousness. In 2013, twenty-five films produced in Russia were released in Ukraine as compared to four in Ukraine. As a result, the average number of visitors to Russian films was 82,400, Ukrainian films 38,950 - two times less. Also, in the field of literature, until 2014 there was no balance between Ukrainian and Russian publishing houses. According to the Ukrainian Publishers Association, Ukrainian books accounted for $8-20 \%$ of the Ukrainian market. The remaining books were imported, $75 \%$ of which came from Russian publishing houses (Олішевська, 2015). So, Ukrainians practically consumed only content made in Russia and this is an unprecedented case in contemporary history.

On December 17, 2013, it seemed that the last fight for Ukraine was over; Yanukovych refused to sign the EU Association Agreement, reaching another agreement with the Russian Federation instead. President Putin agreed to give Ukraine 15 million dollars of financial help and a 33\% discount on natural gas (Volovich, 2014). The agreement with the Russian Federation in 2013 (Minsk) was signed amid mass protests in Ukraine under the slogan of rapprochement with the EU.

After Euromaidan the level of bilateral cooperation went down to its historical minimum. In February of 2014, the Kremlin claimed that an unconstitutional armed seizure 
of power took place in Ukraine, although the Verkhovna Rada, which was elected in October 2012, continued to work in full force. In March of 2014, almost without a single shot fired, the RF annexed Crimea (Постановление Совета, 2014). On June 26, 2014, Petro Poroshenko stated that bilateral relations with Russia could not be normalized until Russia returned control over Crimea to Ukraine (Президент України, 2014). So, practically all Russian-Ukrainian relations are frozen on long-term perspective.

\section{CONCLUSIONS}

After 1991, the goal of Moscow was 'a friendly and neutral Ukraine.' The relations were built primarily on an economic basis, but even then Russia widely used a ban on the import of some goods as a political instrument. Additionally, between 2004-2011 the 'information war' conducted by Russia against Ukraine sporadically repeated ('gas,' 'cheese,' and 'milk' wars). After 2004, problems in Russian-Ukrainian relations related to the Russian military base in Crimea and the basing of the Russian Black Sea Fleet aggravated. After the Orange Revolution, the Kremlin tried to destruct Ukraine rather than let it go its own way - to Europe. Therefore, the RF insisted that Russians and Ukrainians are one nation, that the Ukrainian language is a Russian dialect, etc. All these activities of Russia witnessed are against the contemporary concept of strategic partnership, which was the foundation of Russian politics towards Ukraine. Rather, the RF used very old policy of 'stick and carrot' (low gas prices and other economic preferences as the carrot, responsibility for 'compatriots' as the stick). After all, in 2008 Russia withdrew from the Ukrainian-Russian intergovernmental agreement on SPRN, and artificially increased the number of 'Russians' in Crimea. After 2013, Russia presented Ukraine as a failed state and the Treaty on Friendship, Cooperation, and Partnership was denounced by the RF State Duma. So, the RF itself refuses from being in a 'strategic partnership' with Ukraine. Russia chooses hard power instruments, totally incompatible with the concept of 'strategic partnership.'

The development of modern Russian-Ukrainian relations is overburdened by socio-economic, political, and ideological problems. The sense of unity generated by the common Soviet past gradually disappeared and is replaced by the search for a new identity - dramatic for both societies. They have a high level of mutual distrust, especially because in the past they were so close. In Ukraine, there is a struggle between liberal Europe-oriented ideas and traditional nationalism of the smaller nation. In Russia, Putin received consensus on the base of both traditional patriotism and a new postimperial nationalism. There is an impression that in Russia both the political elites and the society are obsessed with Ukraine. There are several reasons for this: the struggle of the Kremlin with colour revolutions in effort to prevent the same scenario in Russia; the perception of Ukraine as a mirror reflection of Russia; 'East Slavic' ideology; Putin's beliefs that Ukraine is 'an artificial country' and 'a state which failed.' So, the countries that declared themselves strategic partners entered a period of protracted conflict because of differences in their development models.

Russia has already shown the breadth of its geopolitical ambitions and intends to act from the standpoint of 'Russian civilization' versus the West. Putin explained the 
origin of the Russian-Ukrainian conflict by the haste with which the USA promoted the expansion of democracy and the EU sought association with Ukraine: it was perceived by Russia as an invasion of the West on the territory which was considered as a space of its vital interests. Russia seeks to acquire an unofficial right of veto to prevent the further expansion of NATO and the EU to the East. The neutrality imposed on Ukraine on the international level, first of all, would mean Russia's ability to influence the situation in Ukraine much more than the EU. The status of a buffer state would have become a factor that affirmed the tumultuous situation, not only in Ukraine, but also in the whole region.

\section{REFERENCES}

Astrov V., Havlik P. (2007), Belarus, Ukraine and Moldova: Economic Developments and Integration Prospects, in: The New Eastern Europe: Ukraine, Belarus, Moldova, (eds.) D. Hamilton, G. Mangott, Wash.-Vienna.

Barbashin A., Thoburn H. (2015), Ivan Ilyin and the Ideology of Moscow's Rule, https://www. foreignaffairs.com/articles/russian-federation/2015-09-20/putins-philosopher (09.07.2019).

Blanko L. (2011), Strategic Partnership: a new form of association in International Relations?, WISC Conference, http:/www.wiscnetwork.org/porto2011/papers/WISC_2011-523.pdf (09.07.2019).

Brusylovska O. (2015), Russian-Ukrainian conflict. First stage: propaganda war, „Вісник ОНУ. Серія: Соціологія і політичні науки”, Vol. 20, No. 2 (23).

Czechowska L. (2013), The concept of strategic partnership as an input in the modern alliance theory, „The Copernicus Journal of Political Studies”, No. 2 (4).

Darczewska J. (2014), The Information War on Ukraine: New challenges, Cicero Foundation Great Debate Paper 14/08.

Emerson M., Tocci N., Vahl M., Whyte N. (2001), The Elephant and the Bear: the European Union, Russia and their Near Abroad, Brussels.

Emerson M. (2007), Ukraine and the European Union, in: The New Eastern Europe: Ukraine, Belarus, Moldova, (eds.) D. Hamilton, G. Mangott, Wash.-Vienna.

Kovalova E. (2007), Ukraine and Its Neighbours. Ukraine's Role in Changing Europe, in: The New Eastern Europe: Ukraine, Belarus, Moldova, (eds.) D. Hamilton, G. Mangott, Wash. -Vienna.

Le The Mau (2016), Identifying strategic partnership in globalization and international integration era, „National Defence Journal”, September 13, http://tapchiqptd.vn/en/research-anddiscussion/identifying-strategic-partnership-in-globalization-and-international-integrationera/9297.html (09.07.2019).

Moraes L. F. de (2015), On the uses and functions of 'strategic partnership' in international politics: Implications for agency, policy and theory, Bielefeld.

Mendelson S. E. (2016), Generation Putin. What to Expect from Russia's Future Leaders, http:// www.foreignaffairs.com/articles/142488/sarah-e-mendelson/generation-putin?cid=nlcforeign_aff (09.07.2019).

Pasitselska O. (2017), Ukrainian crisis through the lens of Russian media: Construction of ideological discourse, „Discourse \& Communication”, Vol. 11, No. 6, DOI: $10.1177 / 1750481317714127$. 
Piontkovsky A. (2016), Ukraine between Russia and the EU, „National Security and Defence Journal", www.razumkov.org.ua/...journal/NSD_133-134_eng_1.pdf (09.07.2019).

Popescu N., Wilson A. (2009), The Limits of Enlargement-lite: European and Russian Power in the Troubled Neighbourhood, European Council on Foreign Relations.

Slobodchikoff M. O. (2013), Strategic Cooperation. Overcoming the Barriers of Global Anarchy, Lexington.

Subramanian N. (2016), In the promiscuous world of international relations, elements of a strategic partnership, „The Hindu”, October 18, http://www.thehindu.com/opinion/op-ed/ In-the-promiscuous-world-of-international-relations-elements-of-a-strategic-partnership/ article13368545.ece (09.07.2019).

Trenin D. (2007), Russia and Ukraine, in: The New Eastern Europe: Ukraine, Belarus, Moldova, (eds.) D. Hamilton, G. Mangott, Wash.-Vienna.

Volovich O. (2014), Battle of Ukraine, „Borysfen Intel”, http://bintel.com.ua/en/guests/bitva-zaukrainu/ (09.07.2019).

White S., McAllister I., Feklyunina V. (2010), Belarus, Ukraine and Russia: East or West? „The British Journal of Politics and International Relations", No. 12.

Брусиловська О. (2016), Кейси Криму та «Новоросії» у контексті нових викликів європейській безnеuі, „Studia Politologica Ucraino-Polona”, No. 6.

Горбулін В., Литвиненко О. (2010), Украӥно-російські відносини: зачікавлений погляд, http:// cfsp.org.ua/en/publications /papers/43-2010-01-27-15-29-08 (09.07.2019).

Договор о дружбе (1999), Договор о дружбе, сотрудничестве и партнерстве между Российской Федерацией и Украиной, 31 мая 1997 г., „Бюллетень международных договоров”, No. 7.

Дубовик В. (2016), Дискусія американських науковців щзодо ядерної зброї на терені Украӥни y 1992-1993 роках, in: Міжнародні відносини та політика держав в умовах глобальних трансформацій: аналіз сучасної політичноїдумки, (eds.) I. М. Коваль, О. І. Брусиловська, Одеса.

Єхануров Ю. (2018), Схануров: Якби я був міністром оборони, ми протягом п'яти днів повторили б те, щзо зробили у 2008-му під час навчань, 24 квітня, https://gordonua.com/ ukr/news/politics/jehanurov-jakbi-ja-buv-ministrom-oboroni-mi-protjagom-p-jati-dniv-povtorili-b-te-shcho-zrobili-v-2008-mu-pid-chas-navchan-242894.html (09.07.2019).

Жовква I. І. (2005), Стратегічне партнерство у зовнішній політиці України, Київ.

Конщепџия внешней политики (2016), Концепция внешней политики Российской Федерации. Указ Президента Российской Федеращии, http://www.mid.ru/foreign_policy/news/-/ asset_publisher/cKNonkJE02Bw/content/id/2542248 (09.07.2019).

Любашенко В. І. (2019), Денонсаиія міжнародних договорів між Украӥною та Росією у світлі агресії Росії проти України, „Правова держава”, о. 33.

Олішевська В. Д. (2015), Есенціям'якої сили неліберальноїдемократії,„Вісник ОНУ. Соціологія і політичні науки”, Vol. 19, No. 1 (20), DOI: 10.18524/2304-1439.2014.1(20).39443.

О Стратегии (2015), О Стратегии национальной безопасности Российской Федерачии. Указ Президента Российской Федерации No 683, http://kremlin.ru/acts/bank/40391/page/1 (09.07.2019).

Парахонський Б. (2005), Нові реалії двосторонніх відносин Украӥни та Росї: виклики та перспективи, in: Украӥна: стратегічні пріоритети. Аналітичні очінки, Київ.

Парахонський Б., Яворська Г. (2011), Стратегічне партнерство Украӥни. Аналітична запис$\kappa a$, http://www.niss.gov.ua/articles/600/ (09.07.2019). 
Перепелиця Г. М., Заремба О. В., Д’аньєрі П., Кременюк В. О. (2005), Асиметрія міжнародних відносин, Київ.

Пивоваров А. С. (2009), Проблема стратегічного партнерства в зовнішньополітичній діяльності України, Чернівці.

Постановление Совета (2014), Постановление Совета Федерации Федерального Собрания Российской Федерации от 1 марта 2014 года N 48-СF города Москва «Об использовании Вооруженных Сил Российской Федерации на территории Украиныр, http:// rg.ru/2014/03/05/voyska-dok.html (09.07.2019).

Президент України (2014), Виступ Президента України на сесії ПАРС (частина 1), https:// www.president.gov.ua/videos/vistup-prezidenta-ukrayini-na-sesiyi-parye-chastina-1-24 (09.07.2019).

Седляр Ю. О. (2005), Стратегічне партнерство в українсько-російських відносинах, Київ.

Соглашение о параметрах (1999), Согламение между Российской Федерацией и Украиной о параметрах раздела Черноморского флота, 28 мая 1997 г., „Бюллетень международных договоров", №. 10.

Соглашение о статусе (1999), Соглашение между Российской Федерацией и Украиной о статусе и условиях пребывания Черноморского флота Российской Федерации на территории Украины, 28 мая 1997 г., „Бюллетень международных договоров”, No. 10.

Сушко О. (2008), Україна - наступна?, „Українська правда”, 12.08.2008, http://www.pravda. com.ua/articles/2008/08/12/3517426/?attempt=1?attempt=2 (09.07.2019).

Тоді Ф. (2001), Нарис історії Європейського Союзу, Київ.

УКМЦ (2018), Третина новин на російському телебаченні присвячена Украӥні, 23 травня, http://uacrisis.org/ua/66976-grupa-z-analizu-gibridnih-zagroz-ucmc (09.07.2019).

Угода (2010), Угода між Україною та Російською Федерачією з питань перебування Чорноморського флоту Російської Федераиії на території України (Угоду ратифіковано Законом № 2153-VI (2153-17), http://zakon3.rada.gov.ua/laws/show/643_359 (09.07.2019).

Ялі М. Х., Філенко І. В. (2013), Інформаційна політика Російської Федерації щзодо України на початку XXI cm., „Актуальні проблеми міжнародних відносин”, Vol. 11, No. 2.

\begin{abstract}
The hypothesis of this research was that these states never had a rich level of strategic partnership (despite the officially proclaimed status), but always remained a sort of "negative strategic dependence" because of the high level of asymmetry in their relations. I. Zhovkva proved that the attribute of strategic partnership is community of strategic interests; without its further reflections existing relations are superfluous. G. Perepelytsia marked that scientists must distinguish two definitions of strategic partnership - as a level of the attained cooperation and as an instrument of state foreign policy. In the given article strategic partnership is examined in two measures. The first part is sanctified to the use of the concept of strategic partnership in the foreign policy of the Russian Federation (on the example of Ukraine), and second to accordance of level of their cooperation proclaimed strategic partnership. After 1991, the goal of Moscow was 'a friendly and neutral Ukraine.' The relations were built primarily on an economic basis, but even then Russia widely used a ban on the import of some goods as a political instrument. After 2004, problems in Russian-Ukrainian relations related to the Russian military base in Crimea and the basing of the Russian Black Sea Fleet aggravated. Kremlin tried to destruct Ukraine rather than let it go its own way; these witnessed against the contemporary concept of strategic partnership, which was the foundation of Russian politics towards Ukraine. Rather, the
\end{abstract}


RF used very old policy of 'stick and carrot' (low gas prices and other economic preferences as the carrot, responsibility for 'compatriots' as the stick). The Treaty on Friendship, Cooperation, and Partnership between Ukraine and the Russian Federation was denounced as well as all Russian-Ukrainian agreements on the Black Sea Fleet, so, the RF itself refuses from using 'strategic partnership' as instrument of its policy towards Ukraine.

Keywords: Russia, Ukraine, strategic partnership, foreign policy

\section{POLITYKA ROSYJSKA WOBEC UKRAINY: CZY TO KIEDYKOLWIEK BYLO PARTNERSTWO STRATEGICZNE?}

\section{STRESZCZENIE}

W artykule postawiono hipotezę, że partnerstwo strategiczne Rosji i Ukrainy nigdy nie znajdowało się na wysokim poziomie (wbrew oficjalnie głoszonej wersji), będąc raczej - z powodu wysokiego poziomu asymetrii w ich relacjach - swego rodzaju „negatywną zależnością strategiczną". I. Żowkwa twierdzi, że atrybutem partnerstwa strategicznego jest wspólnota interesów strategicznych, a relacje które nie stanowią odzwierciedlenia takiej wspólnoty są zbędne. G. Perepelytsia podkreśla, że naukowcy muszą rozróżnić dwie definicje partnerstwa strategicznego - jako poziom osiągniętej współpracy i jako instrument polityki zagranicznej państwa. Artykuł analizuje dwa aspekty partnerstwa strategicznego. Pierwsza część poświęcona jest wykorzystaniu koncepcji partnerstwa strategicznego w polityce zagranicznej Federacji Rosyjskiej (na przykładzie Ukrainy), a druga - poziomowi współpracy deklarowanej jako partnerstwo strategiczne. Po 1991 roku celem Moskwy była „przyjazna i neutralna Ukraina”. Relacje budowano przede wszystkim w dziedzinie gospodarczej, ale nawet wówczas Rosja intensywnie stosowała instrument polityczny w postaci zakazu importu niektórych towarów. Po 2004 r. relacje rosyjsko-ukraińskie zaostrzyły się w związku z rosyjską bazą wojskową zlokalizowaną na Krymie i stacjonowaniem rosyjskiej floty czarnomorskiej. Kreml był gotów raczej zniszczyć Ukrainę, niż pozwolić jej wybrać własną drogę, co zaprzeczało współczesnej koncepcji partnerstwa strategicznego, będącej fundamentem rosyjskiej polityki wobec Ukrainy. Zamiast tego Federacja Rosyjska zastosowała politykę „kija i marchewki” (niskie ceny gazu i inne preferencje ekonomiczne jako marchewkę, odpowiedzialność za „rodaków” jako kij). Traktat o przyjaźni, współpracy i partnerstwie pomiędzy Federacją Rosyjską i Ukrainą został wypowiedziany, tak samo jak i wszystkie porozumienia dotyczące Floty Czarnomorskiej, tym samym więc, Rosja nie chce posługiwać się formą ,partnerstwa strategicznego" jako instrumentem swojej polityki wobec Ukrainy.

Słowa kluczowe: Rosja, Ukraina, partnerstwo strategiczne, polityka zagraniczna 